\title{
Hizmetler Sektöründe Kadın Çalışanların İş Tatmin Düzeyleri ve Pozitif Psikolojik Sermaye Arasındaki İlişkiye Yönelik Bir Alan Araştırması*
}

\begin{abstract}
Özgür TOPKAYA*๑ Gülşah KORUCU***

Öz

Kadınların işgücüne kathlım oranlarıın genel olarak gelişmiş ülkelerde, gelişmekte olan ülkelere nazaran yüksek olması bu alanda yapılan çalışmaların sayısının artmasına neden olmaktadır. Özellikle hizmetler sektöründe yoğun olarak çalışan kadınların iş tatmin düzeyleri ve çalışma hayatına karşı bakış açılarının belirlenmesi onların işgücü piyasasına katılımları ile ilgili yapılacak çalışmalara rehberlik etmesi bakımından önem taşımaktadır. Bu çalışmanın amacı dünyada ve Türkiye'de istihdamın en yoğun olduğu sektör olan hizmetler sektöründe belirlenen beş alt sektörde kadın işgücünün iş doyumu ve pozitif psikolojik sermaye birikimleri arasındaki ilişkiyi yürütülen bir saha araştırması ile Çanakkale ili özelinde ortaya koymaktır. Çalışmanın kadın işgücü ve hizmetler sektörüne yönelik olması önemini teşkil etmektedir. 422 katılımcının yer aldığı araştırmada ortaya çıkan bulgular, katılımcıların iş tatmin düzeylerinin ve pozitif psikolojik sermaye birikimlerinin yüksek olduğunu ortaya koymaktadır. Araştırma sonuçları iş doyumu yüksek bireylerin pozitif psikolojik sermaye birikimlerinin de yüksek ve iş tatmini en düşük alt hizmet sektörünün ise mali hizmetler (banka çalışanları) ve sigortacılık olduğunu ortaya koymaktadır.

Anahtar Kelimeler: Iş̧ Tatmini, Pozitif Psikolojik Sermaye, Hizmetler Sektörü, Çanakkale

\section{A Research Study over the Relationship between Job Satisfaction and Positive Psychological Capital among Female Employees in the Services Industry}

\begin{abstract}
Female labor force participation rate is higher in developed countries compared to the developing ones. Causes of this dilemma increase the number of scholarly studies in this field. Particularly female employment is higher in the services industry and studies over this sector would guide studies in female employees' job satisfaction levels and their perceptions about work-life. The study aims to investigate the relationship between job satisfaction and positive psychological capital in 5 sub-industries of services industry, major employment industry in Turkey and in the world, over female employees by using a field research in the case of Canakkale Province in Turkey. The
\end{abstract}

Bu çalışma Çanakkale Onsekiz Mart Üniversitesi, Sosyal Bilimler Enstitüsü, Çalışma Ekonomisi ve Endüstri ilişkileri Anabilim Dalı bünyesinde Gülşah KORUCU tarafindan hazırlanan ve 2016 yılında kabul edilen "Pozitif Psikolojik Sermaye Bağlamında Hizmet Sektörlerinde Kadın İş Gücünün İş Tatminini Etkileyen Faktörler: Çanakkale İli Örneği " başlıklı Yüksek Lisans Tezinden türetilmiştir.

** Yrd. Doç. Dr., Çanakkale Onsekiz Mart Üniversitesi, Biga İktisadi ve İdari Bilimler Fakültesi, Çalışma Ekonomisi ve Endüstri İlişkileri Bölümü, ozgurtopkaya@gmail.com

(c) Sorumlu Yazar/Corresponding Author

*** Çalışma Ekonomisi ve Endüstri İlişkileri Uzmanı, gulsah_korucu@hotmail.com 
significance of the study arises from the research subject of the study, female employees and services industry. The research included 422 participants and findings revealed that the participants' level of job satisfaction and positive psychological capital were high. The study concluded that a positive relationship existed between job satisfaction and positive psychological capital while financial and insurance services sector employees scored the lowest job satisfaction levels.

Keywords: Job Satisfaction, Positive Psychological Capital, Services Industry, Çanakkale

\section{GíRiş}

Emek piyasasına girişin oldukça zorlaştı̆̆ bugünün çalışma yaşamında; iş bulmayı başaran bireylerin şanslı olduğu yönündeki görüş çeşitli akademik, iş ve sosyal çevrelerce kabul görmektedir. İşsizlik oranlarının yüksekliği, enflasyon, 2008 Küresel Ekonomik Krizinin süreğenliği, yeni iş yaratma oranlarında beklenen artışın gerçekleşmemesi ve dünyada yaşanan siyasi çalkantılar bu görüşü destekler niteliktedir. Böylesine karamsar faktörlerin yanında yeni üretim ve yönetim tekniklerinde kaydedilen gelişmeler Endüstri 4.0’a doğru yeni bir dönemin kapılarının aralanmakta olduğuna dair izler taşımaktadır. Bu yeni dönemde nitelikli işgücüne olan ihtiyacın giderek artacağı sanal üretim ağları ile fiziksel üretim ağlarının birleşeceği öngörülmektedir.

Teknolojik gelişmeler işletmelerin üretim çıktılarında kayda değer artşlara yol açarken birtakım yeni problemleri de beraberinde getirmektedir. Endüstriyel robotların üretimde kullanılmaları gün geçtikçe artarken ortaya çıkan bir problem söz konusu makinelerin insanlar kadar esnek olamamalarıdır. Özellikle müşteri beklentilerine yönelik talep bazlı üretim yapan işletmelerde bu durum büyük sorunlara yol açmaktadır. Teknolojiyi kullanan işgücünün işini yaparken motivasyonunu kaybetmemesi rekabet edebilirlik, verimlilik ve toplam kalite açısından büyük önem taşımaktadır. Çalışanların motivasyon ve performanslarının verimlilik üzerine etkileri bulunmaktadır. İşletmeler sürekli olarak çalışanların motivasyon ve performanslarının yüksek düzeyde olması için gayret gösterirler. Bu şekilde teknolojik birikimlerinin beraberinde nitelikli insan kaynakları yoluyla da verimliliklerini arttırmaya çalışırlar.

İşletmeler açısından dinamik bir yapı arz eden piyasa ortamı içerisinde hayatta kalmak ve rekabet edebilirliğini korumak büyük öneme sahiptir. Bu nedenle çalışanlar örgütsel düzeyde değerlendirilmekte ve bireysel farklılıklar bahsedilen faktörler sebebiyle göz ardı edilebilmektedir. Ancak iş tatmini ve pozitif psikolojik sermaye ile ilgili yapılan araştırmalarda bu iki faktörün rekabet üstünlüğü sağlayan sermaye türlerinde belirleyici gruplardan olduğu görülmektedir. Çalışanlar sadece iş buldukları için bir süreliğine tatmin olsalar da, zaman içerisinde çalışanların işe bağlııklarının devamının sağlanması için sadece sahip oldukları işin yeterli olmadığı görülmektedir.

\section{1. iş TATMINI VE POZITIF PSIKOLOJIK SERMAYE KAVRAMLARI}

Iş tatmini, işgörenin çalışmakta olduğu işinde ne kadar mutlu olduğunun belirlenmesi (Erdil vd. 2004:18) aynı zamanda da, çalışanların çalışmakta oldukları işlerinden duydukları memnuniyet veya memnuniyetsizliktir (Davis, 1998:96). Öte yandan iş görenlerin çalışmakta oldukları işlerine devamlılığı, örgütüne olan bağlılığı, işini çekici bulması ve 
verimliliği için önemli bir unsurdur (Baş ve Ardıç, 2002: 73). İş tatmini, en genel anlamda, bireyin belirli bir işe karşı olan olumlu duygusal tepkileri şeklinde ifade edilebilir. İşten umulan ve kazanılan maddi çıkarlar çalışanın birlikte çalışmaktan mutluluk duyduğu çalışma arkadaşları ve eser meydana getirmenin sağladığı zevk iş tatmini olarak tanımlanmaktadır (Eren, 2004:202). Demirel (1989: 13)'e göre iş tatmini; ücret, yapılan iş, işin çalışma koşulları, çalışana verilen sosyal hizmetler, iş̧̧inin geleceğe yönelik güvenlik duygusu, toplumsal statü, karar verebilme, yeteneklerini kullanabilme, sahip olunan yetki ve sorumluluk, başarı ve terfi olanakları elde etme, iş arkadaşları ve yöneticileriyle ilgili iyi ya da kötü duyguların bütünüdür (Demirdağ 2015: 49). Tanımlar neticesinde iş görenin yapmakta olduğu iş intiyaçlarını karşılamanın yanı sıra duygu ve değerlerini de etkiliyorsa, iş tatmini başlıyor demektir (Aksu , 1995: 46).

Pozitif psikoloji hareketi, 1990 'lı yılların sonunda Prof. M. Seligman ve arkadaşları tarafindan yürütülen çalışmalar sonucunda ortaya çıkarılmış ve örgütsel davranış konusunda büyük ilgi görmüştür. Daha sonra alan ile ilgili Prof. F. Luthans önemli katkılar sağlamıştır. Çalışmalarında çalışanların güçsüz noktalarına dikkat çekmek yerine güçlü yanlarının odak noktası yapılmasına, çalışanların güçlü yanlarının ardındaki psikolojik durumlarını ölçmeye, geliştirmeye ve yönetmeye çalışarak iş yerinde performansta iyileşmeleri amaçlayan bir yaklaşım ortaya koymuştur (Luthans and Youssef, 2004:152).

Pozitif Psikolojik Sermaye tanımı bireylerin güçlü yönlerine yönelik bir tanım ile dile getirilmiştir. Bu tanım irdelendiğinde dört boyut ortaya çıkmaktadır. Bunlar;

- Zorlu görevlerde başarıya ulaşmak için gerekli çabayı göstermeyi sağlayacak güvene ya da başka bir deyişle öz yeterliliğe sahip olma,

- Şu anki zamanda ve gelecekte başarılı olabilme intimaline dair pozitif beklenti ya da iyimser olma,

- Belirlenen hedeflere ulaşma yolunda azim gösterme ve başarı elde etmek için yeni yollara yönelme başka bir deyişle umut,

- Yaşanılan problemlerle ya da olabilecek sıkıntılarla karşı karşıya kalındığında toparlanabilme ve ısrarcı bir tutumda olma yani dayanıkılık

şeklindedir (Keser ve Kocabaş 2014: 5; Maclnnis ve Melo, 2005).

Umut; gelecekte ulaşılması istenilen fakat henüz ulaşımamış hedeflere ulaşılacağına dair beklenti düzeyini ifade etmektedir. Dayanıklılık, istenilmeyen durumların yanı sıra, sıra dışı pozitif bir durumla karşı karşıya gelindiği zamanlarda diğerlerinin beklenmedik tepkileriyle yüz yüze gelinse dahi baskı ve stres oluşma intimallerini de göğüsleyerek belirlenen hedefler doğrultusunda kararlı biçimde yürümektir (Keser ve Kocabaş, 2014: 5). İyimserlik, iş hayatında ki iyi motive edici, moral veren, fazla beklentili olan ve olumlu amaçlara sahip, zorluklar karşısında daha dik duran, kişisel yeterlilikleri daha az, fiziksel olarak ve ruhsal açıdan daha canlı bireylerin ruh halini açıklamaktadır (Çalışkan ve Erim, 2010:265). Öz yeterlilik ise, motivasyonunu ve bilişsel kaynaklarını, hayatındaki olayları kontrol edecek şekilde kanalize etmesi ve yaşamında karşılaştı̆̆ sorunları çözebileceğine dair inancıdır (Stajkovic and Luthans, 1998: 66). Kendine olan inancıyla ilişkilidir.

Bireyler, farklı duygulara ve davranışlara sahiptir. Bu sebeple içinde bulundukları durumları algılama biçimleri ve ortaya koyacakları davranışlar farklılık göstermektedir. Örgütlerde bireylerin sahip oldukları psikolojik birikimin üretimi ve verimliliği olumsuz etkile- 
memesi üzerine odaklanır. Dolayısıyla psikolojik sermaye, örgütlerde çalışanların güçlü ve olumlu yönlerinin tespit edilmesi ve bunların nasıl su yüzüne çıkarılıp geliştirileceği üzerine yoğunlaşmaktadır. Bu bakımdan psikolojik sermaye iş görenlerin çalışmakta oldukları işlerine yönelik tutum ve tavır geliştirme süreçlerinde önemli bir rol oynamaktadır (Luthans, 2002: 59 ve Gohel, 2012: 35 'den aktaran Biçkes vd 2014, 103). Çalışanların sahip oldukları psikolojinin pozitif yönlü olması işletmede verimlilik ve üretkenlik ile doğrudan ilişkilidir.

İş tatmini iş görenin çalışmakta olduğu işini ve işindeki tecrübesini değerlendirmesi sonucunda sahip olduğu pozitif his veya memnuniyetlik durumu olduğundan ve iş tatmininin bilişsel ve duygusal yanlarının ikisini de barındırması bakımından oldukça kapsamlı bir unsurdur. İnsan psikolojisinde, biliş ile duygular arasında bir bağ vardır ve bunun neticesinde yapılan işin değerlendirilmesinde hem duyguları hem de bilişi yani düşünceleri bu değerlendirmeye katmak gerekmektedir. Iş̧ tatminini etkileyen faktörler arasında pozitif ve negatif duygu durumu ve ruh hali gibi duygusal faktörler özellikle son zamanlarda oldukça geniş bir şekilde incelenmeye başlanmıştır. Son yıllarda yapılan birçok araştırma, duyguların çalışma yaşamındaki rolüne odaklanmıştır. Ashforth ve Humphrey (1995) duyguların örgütsel yaşamla iç içe olduğunu ve örgüt yaşamının ayrılmaz bir parçası olduğunu, bu nedenle de çalışanların duygusal durumlarına daha fazla önem verilmesi gerektiğini vurgulamışlardır (Gürbüz ve Yüksel, 2008, 174). Bu nedenle iş tatmini olgusu oldukça önem kazanmıştır. İş tatmininin, çalışanların motivasyon ve performansları, işyeri devamsızlığı, işgören devri ve örgütsel vatandaşlık davranışı ile olan anlamlı ilişkisi, örgütlerin ve akademisyenlerin bu kavrama olan ilgilerini artırmıştı. Bireyin kişiliği ile ilgili etmenler ve değerler de iş tatmini araştırmalarında etkisi incelenen faktörler arasındadır. Bireyin kişisel özellikleri; bilişsel, davranışsal ve duygusal süreçler üzerinden tavır ve tutumlarını etkilediği için, kişilik özelliği etmeni ile iş tatmini ilişkisinin incelenmesi anlamlı ve önemli hale gelmiştir (Akçay, 2012:217).

\section{HIZMETLER SEKTÖRÜNDE KADIN ÇALIŞANLARA YÖNELIK IŞ TATMINI VE PSIKOLOJIK SERMAYE ÇALIŞMALARI ÜZERINE LITERATÜR TARAMASI}

Sanayileşme sürecine paralel olarak tarım, sanayi ve hizmetler sektöründe istihdam oranları değişme göstermektedir. 1800'lü yıllarda tarım sektöründe yoğun olan istihdam bir süre sonra sanayi sektörüne doğru kaymış ve 1950'li yıllara gelindiğinde ise hizmetler sektörü en fazla istihdam kapasitesine sahip sektör olarak öne çıkmıştır. Kadınların iş gücüne katlımı da hizmetler sektörünün gelişimine paralel bir seyir göstermiştir. Özellikle gelişmiş ülkelerde kadınların hizmetler sektöründe yoğun olarak istihdam edildikleri görülmektedir. İş tatmininin çalışanlar üzerindeki etkileri ve sonuçları önemli bir araştırma konusu olmaktadır. Günümüzde iş tatmini ve pozitif psikolojik sermaye arasındaki ilişkiyi inceleyen çalışmalar mevcuttur.

Topçu ve Ocak (2012) çalışmalarında iş tatmini ve pozitif psikolojik sermaye arasındaki ilişkiyi araştırmışlardır. Bosna Hersek örnekleminde 268 kişi, Türkiye örnekleminde 125 kişi ankete iştirak etmiştir. Ankete katılan Bosna Hersek örnekleminde yer alan çalışanların cinsiyete göre dağılımları \%50 kadın ve \%50 erkek, yaşlarının ortalaması 42,5 ve kıdemleri ortalaması 20,3 tür. Yazarlar, çalışmada kuramdan yola çıkarak oluşturdukları yapısal eşitlik modelini ölçmek için Ergin'in (1992) çalışmasında Türkçeye uyarlanan mesleki tükenmişlik ölçeğini, Çetin ve Basım'ın (2011) çalışmalarında Türkçe'ye uyarla- 
nan psikolojik sermaye ölçeğini ve Şeşen'in 2010 tarihli çalışmasında Türkçe'ye uyarladığı iş tatmini ölçeğini kullanmışlardır. Elde edilen bulgularda, psikolojik sermaye ile tükenmişlik algısının ters yönlü bir ilişki içinde bulunduğu belirtilmiştir. Psikolojik sermaye ile iş tatmininin ise genelde aynı yönlü ilişki sergilerken Bosna Hersek örnekleminde ters yönlü bir ilişki bulunduğu, iş tatmini ile tükenmişlik algısı arasında herhangi bir etkiye rastlanılmadığı, bu nedenle aracılık etkisinden de bahsedilemeyeceği ortaya koyulmuştur.

Akçay'ın (2012) çalışmasında pozitif psikolojik sermayenin ve dört bileşeninin her birinin ayrı ayrı iş tatmini arasındaki ilişkisi araştırılmıştı. Ana kütle olarak kamuda çalışan 450 kişi belirlenmiştir. Yazar çalışanların iş tatmin düzeylerini, T. Oshagbemi tarafindan 1999 tarihli çalışmasında kullandığı ölçekle ve psikolojik sermaye ölçümünü ise Luthans, Avolio, Avey ve Norman'ın (2007a) tarihinde geliştirdikleri ölçekle yapmıştır. Çalışma sonucunda çalışanların pozitif psikolojik sermaye düzeyi ile iş tatmini düzeyi arasında pozitif ve anlamlı bir ilişki olduğu saptanmıştr.

Özer, Topaloğlu ve Timurcanday, Özmen (2013) psikolojik sermaye ve iş doyumu konulu çalışmalarında ana kütleyi sağlık sektöründe faaliyet gösteren bir hastanenin tüm çalışanları olarak belirlemişlerdir. 390 kişiyle anket yapılmıştı. Psikolojik sermaye düzeyini belirlemek amacıyla, Luthans ve arkadaşları (2007b) tarafindan geliştirilmiş olan PsyCap Questionnaire (PCQ) araştırmacılardan izin alınarak ve Türkçeye aktardıkları 12 ifadenin çevirisi kullanılmıştı. Araştırmanın ana hipotezi olarak belirledikleri, destekleyici iklimin, psikolojik sermaye ve iş doyumu ilişkisindeki düzenleyici rolünü sorgulamak için hiyerarşik regresyon analizi yapmışlardır. Çalışmada psikolojik sermaye ile iş doyumu ve performans gibi sonuç değişkenleri arasında pozitif ilişkiler olduğu yönünde bulgular sunulmuştur. Bununla birlikte, araştırmanın esas amacına teşkil eden destekleyici örgüt ikliminin, psikolojik sermaye ile doyum ilişkisini kısmi düzeyde düzenlediği ortaya koyulmuştur.

Kaplan ve Biçkes (2013) Türkiye'de Turizm Bakanlığı tarafindan ruhsatlı beş yıldızı otel işletmelerinin çalışanlarını evren olarak belirlemişlerdir. Çalışmada Nevşehir Şehrindeki yedi otelin çalışanları ana kütle olarak seçilmiştir. Otellerde çalışan 181 kişi ile görüşülmüştür. İş tatmini bu çalışmada bağımlı değişken olarak belirlenmiştir, Psikolojik sermaye boyutları bağımsız değişken olarak kabul edilmiştir. Çalışmada psikolojik sermaye ve iş tatmini kavramlarının çalışanlar için büyük önem taşımakta olduğu ve pozitif psikoloji ile iş tatmini arasında olumlu bir ilişki olduğu gözlemlemiştir.

Duygusal emek ile iş tatmini arasındaki ilişkide psikolojik sermayenin aracılık rolü çaış̧ması yapan Biçkes, Yılmaz, Demirtaş, Uğur (2014), çalışmalarının verilerini lise ve dengi okullarda görev yapan eğitimcilerle yüz-yüze görüşme yöntemiyle uygulanan anket sonrasında elde etmişlerdir. Katlımcıların psikolojik sermaye düzeylerini ölçmek için Luthans ve diğerleri (2007) tarafindan geliştirilen psikolojik sermaye ölçeği kullanılmış ve katılımcıların iş tatmin düzeylerini ölçmek için Minesota İ̧̧ Tatmin Ölçeğinin kısa versiyonu kullanılmıştr. Sonuç olarak psikolojik sermayenin bütün alt boyutları (öz yeterlilik, umut, dayanıklııık ve iyimserlik) ile iş tatmini arasında anlamlı ve pozitif yönlü ilişkilerin bulunduğunu göstermişler ve bu ilişki, psikolojik sermaye düzeyi yüksek olan çalışanların iş tatminini olumlu ve olumsuz yönde etkileyebilecek bireysel ve örgütsel faktörler üzerinde diğer çalışanlara nazaran daha belirleyici olabilmeleriyle, olumsuzluklara göğüs gerebilmeleriyle ve başarıya odaklanmalarıyla açıklanabilir olduğunu söylemişlerdir. 
Şen, Mert ve Aydın (2015) çalışmalarında Ankara ve Malatya bölgelerinde görev yapan çalışanların katılımıyla bir saha araştırması gerçekleştirip hazırladıkları soru formunu 298 katlımcıya uygulamışlardır. Araştırmada beş bölüm 51 sorudan oluşan soru formu kullanılmışttr. Formun ilk bölümü psikolojik sermaye ölçeği ve ikinci bölümde stres ölçeği bulunmaktadır. İş tatmini ölçeği üçüncü bölümü oluşturmaktadır. Son bölümde ise altı sorudan oluşan demografik özellikleri ölçmeye yönelik sorular bulunmaktadır. Kat-lımcılar cinsiyet bakımından incelendiğinde \%81.2'sinin erkek, \%18.8'inin kadın olduğu görülmektedir. Araştırmanın bulguları, bireyin pozitif psikolojik durumunu geliştirmek olarak tanımlanabilen psikolojik sermayenin; örgütsel bağlamda başarı ve performansla ilişkilendirilen temel değişkenlerden olan iş tatmini ve örgütsel bağlılık değişkenleri ile arasında orta düzeyde, pozitif; stres düzeyi ile arasında ise orta düzeyde, negatif yönde bir ilişkinin bulunduğunu ortaya çıkarmıştır

Uygungil (2017), Adana ilinde faaliyet gösteren kamu ve özel sektör hastanelerinde çalışanların pozitif psikolojik sermayeleri ile iş tatmin düzeylerini incelemektedir. Çalışmada 400 'ü kamu hastanelerinde, 400'ü özel hastanelerde olmak üzere toplam 800 çalışana anket gönderilmiş, ancak bunların sadece 500 tanesi toplanabilmiştir. Katlımcıların pozitif psikolojik sermayelerinin ölçülmesi için, Luthans vd. (2007) tarafindan geliştirilen "Psikolojik Sermaye Anketi (PCQ-24)" ve iş tatmini düzeylerinin belirlenmesine yönelik, Churchill, Ford ve Walker (1974) tarafindan geliştirilen iş tatmini ölçeğinin kısa versiyonu (Comer, Machleit ve Lagace, 1989) kullanılmıştır. Verilerin analizinde ise yapısal eşitlik modeli kullanılmıştır. Araştırma sonuçları, pozitif psikolojik sermayenin örgütsel bağııık ve iş tatmini üzerinde pozitif yönlü bir etkiye sahip olduğu buna karşın örgütsel sinizm üzerinde negatif yönlü bir ilişkiye sahip olduğu şeklindedir. Pozitif psikolojik sermaye ile işten ayrılma niyeti arasında bir ilişki ise tespit edilememiştir.

\section{YÖNTEM}

\subsection{Araştırmanın Amacı}

Araştırmanın amacı Çanakkale ili'nde hizmetler sektöründe istihdam edilen kadın işgücünün iş tatmin düzeylerinin ve pozitif psikolojik sermaye birikimlerinin araştırılmasıdır. Bu kapsamda bir anket çalışması yürütülmüştür. Araştırma ile aşağıdaki hipotezlere cevap aranmaktadır. Araştırmanın hipotezleri;

H1 Çanakkale ili'nde hizmetler sektöründe istihdam edilen kadın işgücünün iş tatminleri ile pozitif psikolojik sermayeleri arasında pozitif yönlü bir ilişki bulunmaktadır.

H2 Çanakkale ili'nde hizmetler sektöründe istihdam edilen kadın işgücünün bulundukları hizmet alanına göre iş tatmin düzeyleri ve pozitif psikolojik sermaye birikimleri değişmektedir.

H3 Çanakkale ili'nde hizmetler sektöründe istihdam edilen kadın işgücünün demografik özelliklerine göre iş tatmin düzeyleri ve pozitif psikolojik sermaye birikimleri değişmektedir.

\subsection{Sınırlılıkları}

1. Bu çalışma Çanakkale ilinde hizmetler sektöründe faaliyet gösteren kurumları kapsamakta olup, bu kurumlarda istihdam edilen kadınların görüşleri ile sınırlandırılır.

2. Çalışma sonuçları veri toplama aracı ile sınırlandırılır. 
3. Anketin sonuçları uygulandığı dönemde elde edilen veriler göz önünde bulundurularak yorumlanmaktadır.

4. Araştırma sonuçları iş tatmini ve pozitif psikolojik sermaye arasındaki ilişki incelenerek elde edilmektedir. Farklı değişkenler çalışmanın sonucunu değiştirebilir.

\subsection{Yöntem ve Evren:}

Araştırmanın evrenini Çanakkale ilinde hizmetler sektöründe çalışan kadınlar oluşturmaktadır. 2017 Ocak verilerine göre Türkiye'de 15 yaş ve yukarı çalışan kadın sayıSı 8 milyon 928 bin kişidir (TÜiKa, 2018). Çanakkale ve Balıkesir illerini kapsayan TR22 Bölgesi'nde istihdam edilen 15 yaş ve üzeri kadın çalışan sayısı ise 194 bin kişidir. (TÜiKb, 2018). Hizmetler sektöründe çalışan kadın sayısı ile ilgili güncel veriye ulaşılamamıştır. Ancak Anderson (1990) örneklem- evren tablosuna göre \%5 güven aralığında 100 bin kişilik bir evrende 382 ve 1 milyon kişilik bir evrende 384 kişiye ulaşılması gerekmektedir (Anderson'dan aktaran Balcı, 2005:95). Buna göre Çanakkale ve Balıkesir illerinde çalışan 194 bin kadın çalışanın evren olduğu varsayılsa da bu araştırmada 422 kişiye ulaşılmış olması ulaşılabilen örneklemin yeterli olduğunu göstermektedir. Ayrıca çalışmada ulaşılabilir örneklem metodu kullanılmıştır.

Çanakkale ilinde hizmet sektörlerinde sağlık sektöründe çalışmakta olan 100 kadın iş gören, Eğitim sektöründe çalışmakta olan 100 kadın iş gören, konaklama ve yiyecek sektöründe çalışmakta olan 75 kadın iş gören, mali hizmetler ve sigorta sektöründe çalışmakta olan 75 kadın iş gören, ve mesleki, bilimsel ve teknik faaliyetler sektöründe çalışmakta olan 75 kadın iş gören oluşturmaktadır. 425 kişiye dağıtılan anketlerden üç tanesi çıkarılmıştır. Çanakkale ilinde toplam 422 anket toplanmıştır. Elde edilen bulgular SPSS programına aktarılmıştır. Bu kapsamda Minnesota İş Tatmini Ölçeği ve Pozitif Psikolojik Sermaye Ölçeği, kullanılmıştr. Ölçekler hakkındaki bilgi kısaca aşağıda sunulmuştur:

Minnesota Iş Tatmini Ö/çeği: Bilimsel araştırmalarda daha çok tercih edilen Minnesota iş tatmini ölçeği 1967 yılında Wiess, Dawis, England ve Lofquist tarafindan geliştirilmiştir. Ölçek içsel tatmin, dışsal tatmin ve genel iş tatminini ölçebilmektedir. Minnesota İş Tatmini Ölçeği 1-5 arasında puanlanan likert tipi bir ölçektir. Ölçek puanlamasında, 1- hiç memnun değilim; 5- çok memnunum; olarak değerlendirilmektedir. Ölçekte ters soru bulunmamaktadır. Minnesota iş tatmini ölçeği Baycan (1985) tarafindan Türkçeye uyarlanarak geçerlik ve güvenirlik çalışmaları yapılmıştır ( Aşan ve Özyer, 2008: 74).

Pozitif Psikolojik Sermaye Ölçeği: Çalışanlarının pozitif psikolojik sermaye algılarını ölçmek için Luthans vd. (2007a: 237- 238) tarafindan geliştirilen 24 ifadeli olan ölçek (PCQ24) kullanılmıştır. Ölçekte öz-yeterlilik, umut, iyimserlik ve dayanıklılık olmak üzere dört boyut bulunmaktadır. Her bir boyutta 6 madde bulunmaktadır. Araştırmada ölçeğin geçerlilik ve güvenilirlik çalışmalarının Çetin ve Basım (2012) ile Erkuş ve Afacan-Fındıklı (2013: 309-310) tarafindan yapıldığı Türkçe hali kullanılmıştır.

\section{4. Örneklem:}

Araşttrmaya konu olan verilerin toplanması ve değerlendirilmesi Nisan 2016- Temmuz 2016 tarihleri arasında gerçekleştirilmiştir. Çanakkale ili ve ilçelerindeki hizmet sektörlerinden olan, sağılı, eğitim, konaklama ve yiyecek, mali hizmetler ve sigorta sektörlerinde çalışan kadın iş görenlere yönelik olarak anket uygulaması yapılmıştır. Anket, Ça- 
nakkale ilinde rastgele seçim yöntemiyle, başta merkez ve Biga ilçesi olmak üzere diğer ilçelerinde de uygulanmıştır. 430 kadın çalışan anket uygulamasına katılmıştır. 422 tane anket formu örnekleme dahil edilmiştir.

\section{Tablo 1: Örnekleme Katılan İşgörenlerin Çalışttkları Sektörlere Göre Dağııııı}

\begin{tabular}{lll} 
Sektör Türü & Katılımcı Sayısı & Yüzde \\
\hline Mesleki Bilimsel Teknik & 75 & 17,8 \\
Eğitim & 101 & 23,9 \\
Konaklama ve Yiyecek & 74 & 17,5 \\
Sağlık ve Sosyal Hizmetler & 97 & 23 \\
Mali Hizmetler ve Sigorta & 75 & 17,8 \\
Toplam & 422 & 100
\end{tabular}

\subsection{Verilerin Analizi:}

Elde edilen 422 anket formu kontrol edildikten SPSS 22.0 istatistik paket programına aktarılmıştır. Verilerin analizi SPSS 22.0.dayapılmıştır. IIlk olarak örneklem grubunu oluşturan bireylerin frekans ve yüzdelik dağılımları incelenmiştir. Pozitif psikolojik sermaye ölçeğinin; Çetin ve Basım (2012) tarafindan önerilen dört faktörlü bir yapıya (iyimserlik, psikolojik dayanıklılık, umut, özyeterlilik) uyum gösterip göstermediği Doğrulayıcı Faktör Analizi aracılıyla incelenmiştir. Veriler doğrulayıcı faktör analizinin varsayımlarını karşılamaktadır.

Minnesota iş tatmin ölçeğinin Baycan (1985) tarafından önerilen tek faktörlü bir yapıya uyum gösterip göstermediği Doğrulayıcı Faktör Analizi aracılı̆ııla incelenmiştir. Veriler doğrulayıcı faktör analizinin varsayımlarını karşılamaktadır. Doğrulayıcı faktör analizinde test edilen modelin veriyle uyumu, uyum iyiliği indeksleri aracığıyla incelenmektedir.

İ̧̧ tatmini ölçeğinin iç tutarlılık (güvenilirlik) düzeyine gösteren Cronbach Alpha Değeri, 0,86 olarak hesaplanmıştır. Pozitif psikolojik sermaye ölçeğinin iç tutarlılık (güvenilirlik) düzeyine gösteren Cronbach Alpha Değeri, 0,79 olarak hesaplanmıştır.

\subsection{Bulgular}

Araştırmada çalışma grubuna dahil edilen çalışan bayanlara ilişkin betimsel istatistikler verilmiş, ikinci olarak katılımcıların psikolojik dayanıklılık düzeyleri ve iş doyumu düzeyleri hakkında bilgi sağlanmış, üçüncü olarak, katılımcıların araştırma kapsamında ele alınan değişkenlere (medeni durum, yaş, eğitim durumu, çalışılan yıl, sektör, meslek ve ortalama gelir) göre psikolojik dayanıklılık düzeyleri ve iş doyumu düzeyleri arasındaki farklılıklar incelenmiş ve son olarak demografik değişkenlerin etkisi kontrol edildiğinde psikolojik dayanıklılık düzeyleri ile iş doyumu düzeylerini arasındaki ilişki incelenmiştir. 
Tablo 2: Katılımcıların Demografik Özellikleri (\%)

\begin{tabular}{|c|c|c|c|c|c|c|}
\hline $\begin{array}{l}\text { Medeni } \\
\text { Durum }\end{array}$ & Evli & Bekar & & & & \\
\hline$\%$ & 68,5 & $\% 31,5$ & & & & \\
\hline Yaş & $20-25$ & $26-30$ & $31-35$ & $36-40$ & $41+$ & \\
\hline$\%$ & 12,1 & 19,9 & 15,9 & 33,4 & 18,7 & \\
\hline Eğitim & Orta & Lise & MYO & Üniversite & Y. Lisans & \\
\hline$\%$ & 11,6 & 13,5 & 11,1 & 54,5 & 9,2 & \\
\hline Kıdem & $\begin{array}{l}3 \text { ve daha } \\
\text { az }\end{array}$ & 4-7 yıl & 8-11 yıl & $12-15$ yıl & $\begin{array}{l}16 \text { ve } \\
\text { üzeri }\end{array}$ & \\
\hline$\%$ & 23,9 & 22,7 & 19 & 19 & 15,4 & \\
\hline Meslek & Yönetici & Çalışan & Akademisyen & Bankacı & Hemşire & Öğretmen \\
\hline$\%$ & 13 & 24,6 & 7,1 & 16,8 & 19,9 & 18,5 \\
\hline Gelir & $\begin{array}{l}1000- \\
1500 T L\end{array}$ & $\begin{array}{l}1501- \\
2000\end{array}$ & 2001-2005TL & $2501+T L$ & & \\
\hline$\%$ & 23 & 14,5 & 16,8 & 45,7 & & \\
\hline
\end{tabular}

Tablo 2'de katımcıların demografik özelliklerine yer verilmektedir. Veriler değerlendirildiğinde hizmetler sektöründe çalışan ve ankete katılan kadınların çoğunluğunun evli olduğu görülmektedir. Yaş ortalaması ise 36-40 aralığında \%33,4 ile en yüksektir. Çalışan kadınların büyük çoğunluğu üniversite mezunudur. Kıdem durumları değerlendirildiğinde büyük çoğunluğunun 3 yıl ve az ve 4-7 yıl arasında yoğunlaşttkları görülmektedir. Gelirler ise \%45,7 ile en fazla 2501 TL ve üzerinde yoğunlaşmaktadır.

\section{Tablo 3: İş Doyumu ve Psikolojik Sermaye Ortalama ve Standart Sapmaları}

$\begin{array}{lcc} & \text { Ort. } & \text { S.s. } \\ \text { İş Doyumu } & 3.93 & .50 \\ \text { Psikolojik Sermaye } & 3.98 & .36\end{array}$

Tablo 3'de katılımcıların iş doyumu ve psikolojik sermaye ortalama ve standart sapmaları görülmektedir. Her iki ölçekte beşli Likert tipi bir ölçek olduğundan ölçekte alınabilecek en düşük puan 1 iken en yüksek puan 5' tir. Her iki ölçekten alınan puanların 4' e yakın olduğu görülmektedir. Bu nedenle, araştrrma örneklemini oluşturan bireylerin psikolojik sermaye ve iş doyumu düzeylerinin yüksek olduğu ortaya çıkmaktadır.

Katılımcıların iş doyumu puanlarında medeni duruma göre anlamlı bir farklılık olup olmadığı bağımsız örneklemler için t-testi aracılığıyla incelenmiştir. Bağımsız örneklemler için t-test sonucunda medeni duruma göre iş doyumunun değişmediği bulunmuştur. Katılımcıların iş doyumu puanlarında yaşa göre anlamlı bir farklılık olup olmadığı Tek Yönlü Varyans Analizi (ANOVA) aracılığıyla incelenmiştir. Tek Yönlü ANOVA testi sonucunda yaşın iş doyumu puanlarında anlamlı bir farklıık oluşturduğu görülmüştür. FarklıIığın hangi grup ya da gruplar arasındaki puan farklılığından kaynaklandığını belirlemek amacıyla gerçekleştirilen Games-Howell testi sonucunda 41 yaş ve üzeri olan bireylerin 
(Ort: 4.11), 20-25 yaş (Ort: 3.80), 26-30 yaş (Ort: 3.85), 31-35 yaş (Ort: 3.83) arasındaki bireylerden iş doyumunun anlamlı bir şekilde daha yüksek olduğu görülmüştür. Diğer gruplar arasında anlamlı bir farklılık yoktur.

Tek Yönlü ANOVA testi sonucunda eğitim durumunun iş doyumu puanlarında anlamlı bir farklılık oluşturduğu görülmüştür. Games-Howell testi sonucunda lise mezunlarının (Ort: 4.09) iş doyumu puanlarının lisans mezunlarından (Ort: 3.88) anlamlı bir şekilde daha yüksek olduğu görülmüştür. Diğer gruplar arasında anlamlı bir farklılık yoktur.

Katılımcıların iş doyumu puanlarında çalışma süresine göre anlamlı bir farklılık olup olmadığı Tek Yönlü ANOVA aracılığıyla incelenmiştir. Tek Yönlü ANOVA testi sonucunda çalışma süresinin iş doyumu puanlarında anlamlı bir farklılık oluşturduğu görülmüştür. Farklılığın hangi grup ya da gruplar arasındaki puan farklılığından kaynaklandığını belirlemek amacıyla gerçekleştirilen Scheffe testi sonucunda, çalışma süresi 12-15 yıl (Ort:4.07) ve 16 yıl ve üzeri olan (Ort: 4.11) bireylerin iş doyumu puanlarının çalışma süresi 0-3 y?l (Ort: 3.83) ve 4-7 yıl(Ort: 3.84) bireylerden anlamlı bir şekilde daha yüksek olduğu görülmüştür. Diğer gruplar arasında anlamlı bir farklılık yoktur.

Katılımcıların iş doyumu puanlarında sektöre göre anlamlı bir farklılık olup olmadığı Tek Yönlü ANOVA aracılığıyla incelenmiştir. Tek Yönlü ANOVA testi sonucunda sektörün iş doyumu puanlarında anlamlı bir farklılık oluşturduğu görülmüştür. Farklılığın hangi grup ya da gruplar arasındaki puan farklııı̆ından kaynaklandığını belirlemek amacıyla gerçekleştirilen Games-Howell testi sonucunda sırasıyla şu bulgulara ulaşışmıştr; Eğitim sektörü çalışanlarının (Ort: 4.26), mesleki bilimsel ve teknik (Ort: 3.97), konaklama ve yiyecek (Ort: 4.07), sağlık ve sosyal hizmetler (Ort: 3.77), mali hizmetler ve sigorta (Ort: 3.52) sektörü çalışanlarından iş doyumlarının anlamlı bir şekilde yüksek olduğu görülmüş"tür. Mesleki teknik ve bilimsel sektöründe çalışanların ise iş doyum puanları sağlık ve sosyal hizmetler (Ort: 3.77), mali hizmetler ve sigorta (Ort: 3.52) sektörü çalışanlarından anlamlı bir şekilde daha yüksektir. Benzer şekilde konaklama ve yiyecek (Ort: 4.07) sektöründe çalışanların iş doyum puanları sağlık ve sosyal hizmetler (Ort: 3.77), mali hizmetler ve sigorta (Ort: 3.52 ) sektörü çalışanlarından anlamlı bir şekilde daha yüksektir. Sağlık ve sosyal hizmetler sektöründe çalışanların ise (Ort: 3.77), mali hizmetler ve sigorta (Ort: 3.52) sektörü çalışanlarından iş doyumu anlamlı bir şekilde yüksektir. Mali hizmetlerin iş doyumu (Ort: 3.52) diğer tüm sektörlerin iş doyumundan daha düşüktür.

Katılımcıların psikolojik sermaye puanlarında mesleklere göre anlamlı bir farklılık olup olmadığı Tek Yönlü ANOVA aracılığıyla incelenmiştir. Tek Yönlü ANOVA testi sonucunda mesleklerin psikolojik sermaye puanlarında anlamlı bir farklılık oluşturduğu görülmüştür $(F(5,152.90)=18.94, p<.001)$. Farklılığın hangi grup ya da gruplar arasındaki puan farklılığından kaynaklandığını belirlemek amacıyla gerçekleştirilen Games-Howell testi sonucunda sırasıyla aşağıdaki bulgulara ulaşılmıştır. Üst düzey yöneticilerin(Ort: 4.16), psikolojik sermaye puanlarının çalışanlardan(Ort: 3.94), bankacılardan (Ort: 3.74) ve hemşirelerden (Ort: 3.91) anlamlı bir şekilde daha yüksektir. Benzer şekilde, akademisyenlerin (Ort: 4.23) psikolojik sermaye puanları, çalışanlardan (Ort: 3.94), bankacılardan (Ort: 3.74) ve hemşirelerden (Ort: 3.91) anlamlı bir şekilde daha yüksektir. Çalışanların (Ort: 3.94) psikolojik sermaye puanları, bankacılardan (Ort: 3.74) anlamlı bir şekilde daha yüksektir. Son olarak öğretmenlerin (Ort: 4.06) psikolojik sermaye puanları bankacılardan (Ort: 3.74) anlamlı bir şekilde daha yüksektir. Yukarıda belirtilmeyen, diğer gruplar arasında anlamlı bir farklılık yoktur. 
Katılımcıların psikolojik sermaye puanlarında aylık gelire göre anlamlı bir farklılık olup olmadığı Tek Yönlü ANOVA aracılığıyla incelenmiştir. Tek Yönlü ANOVA testi sonucunda aylık gelirin psikolojik sermaye puanlarında anlamlı bir farklılık oluşturduğu görülmüştür $(F(3,418)=4.12, p<.01)$. Farklılığın hangi grup ya da gruplar arasındaki puan farkıı̆ı̆ından kaynaklandığını belirlemek amacıyla gerçekleştirilen Scheffe testi sonucunda aylık geliri $2501 \mathrm{tl}$ ve üzeri olan bireylerin (Ort: 404) psikolojik sermaye puanlarının 15012000tl arasında olan bireylerden (Ort: 3.90) anlamlı bir şekilde daha yüksek olduğu görülmüştür. Diğer gruplar arasında anlamlı bir farklılık yoktur.

Son olarak, sosyo demografik değişkenlerin etkisi kontrol edildiğinde psikolojik sermaye ile iş doyumu arasında nasıl bir ilişki olduğunu belirlemek için Spearman korelasyon analizi gerçekleştirilmiştir. Analize dahil edilen kontrol değişkenleri medeni durum, yaş, eğitim, durumu, çalışılan yıl, sektör, meslek ve ortalama gelir düzeyidir.

\section{Tablo 4: Pozitif Psikolojik Sermaye ile İş Doyum Arasındaki İlişki}

$\begin{array}{ll} & \text { İş Doyumu } \\ \text { Psikolojik Sermaye } & .49 \\ \text { P } & .001^{*} \\ \text { Sd } & 413\end{array}$

Sosyo-demografik değişkenlerin etkisi kontrol edildiğinde psikolojik sermaye ve iş doyumu arasında orta düzeyde pozitif yönde bir ilişki vardır $(r(413)=.49, p<.001)$. Başka bir ifadeyle sosyo-demografik değişkenler kontrol edildiğinde, psikolojik sermayesi yüksek olan bireylerin iş doyumu yüksek, psikolojik sermayesi düşük olan bireylerin iş doyumu düşüktür.

\section{SONUÇ VE TARTIŞMA}

İ̧̧ tatmini ile bağlantısı olan pozitif psikolojik sermaye iş hayatında çalışanların davranışlarının yalnızca olumsuz ve sorunlu yanlarına değil, aksine olumlu ve iyi taraflarına odaklanıımasını vurgulayan bir alandır. Pozitif psikolojik sermaye çalışanların verimliliklerini ve hayata bakış açılarını olumsuz etkileyen yönlerinin bir şekilde ortadan kaldırılarak, güçlü yanlarının geliştirilmesi ve göz önünde bulundurulmasını vurgulamaktadır. Pozitif psikolojik sermaye Luthans tarafindan "bireyin olumlu yönde gelişmesi" olarak tanımlamaktadır (Luthans ve diğerleri, 2007a). Pozitif psikolojik sermaye, bireyin kendisini tanıması ve umut, öz yeterlilik, iyimserlik ve dayanıkııık ile kendisini tanımlaması ile ilgili olmaktadır. Çalışma hayat bireyi iç dünyasında çeşitli yollara yönlendirebilmektedir. İs stresi yüksek, olumsuz çalışma koşullarının ve ortamların olduğu iş yerlerinde bireyin umudunu, öz yeterliliğini, iyimserliğini ve dayanıklılı̆ını koruması da çok zor olmaktadır. İşletmeler açısından işyerlerinin çalışanlar üzerinde yarattı̆ı psikolojik etkiyi ortaya çıkarmanın bir yolu, çalışanların pozitif psikolojik sermayelerini ölçmekten geçebilir. ÇaIışanlarda pozitif psikolojik sermaye düzeylerinin düşük çıkması işverenlerin işyerinde bir sorun olduğu yönünde fikir sahibi olmalarını da sağlayabilir. Yapılacak bu çalışmalar, işgören, meslek, işkolu ve sektör düzeyinde gerçekleştirilebilir.

Çalışmada hizmetler sektöründe belirlenen alt sektörlerde kadın çalışanlara yönelik bir araştırma gerçekleştirilmiştir. Çalışmanın sonuçları Akçay (2012) ve Özer, Topaloğlu ve 
Timurcanday, Özmen (2013)'in çalışmalarında elde edilen bulgulara benzer olacak şekilde iş tatmini ile pozitif psikolojik sermaye arasında olumlu ilişki olduğu şeklindedir.

Alt sektörler içerisinde en düşük iş doyumunun mali hizmetler alanında olması çalışanların bu alt sektörde karşılaştıkları bir takım zorluklardan kaynaklanmaktadır. Bu sektörde görülen çalışma sürelerinin uzunluğu, satış hedefleri ve meslek hastalıları kadın çalışanların işe bakış açısını olumsuz yönde etkilemektedir. Kadınların hizmetler sektöründe yoğun olarak bulundukları göz önünde bulundurulduğunda, mali hizmetler alt sektöründe kadın çalışanlara yönelik pozitif ayrımcılık yönünde uygulamalara gidilebilir.

Çalışmada pozitif psikolojik sermaye ile iş tatmini arasında olumlu ilişkinin olduğu ve sosyo-demografik değişkenler kontrol edildiğinde, psikolojik sermayesi yüksek olan kadın çalışanların iş doyumunun yüksek, psikolojik sermayesi düşük olanların ise iş doyumunun düşük olduğu saptanmıştır. Birbirleriyle doğru ilişkili olduğu saptanan iki kavramın çalışma hayatına yansıması da paraleldir. Yeni üretim ve yönetim teknikleri kapsamında çalışanları iç müşteri olarak gören ve mutluluklarını en üst düzeye çıkarmaya çalışan toplam kalite yönetimi gibi teknikler önem kazanmaktadır. İşletmeler; çalışanlarının iş tatminlerini ve psikolojik sermayelerini geliştirmeye odaklı programlar ve uygulamalar gerçekleştirmelidir. Bu sayede onların niteliklerini ve işe bakış açılarının olumlu yönde değiştirebileceklerdir. Çalışanların pozitif psikolojik sermaye alanı kişinin geliştirilebilir yönlerini ortaya koyarak bu yönlerinden hareketle bireyin vasıf ve verimlilik düzeyini arttırmayı hedeflemektedir. Mali hizmetler ve sigortacılık sektöründe kadın çalışanların pozitif psikolojik sermaye düzeyleri, diğer sektörlere göre daha düşük çıkmaktadır. Bu alana yönelik gelecekteki araştırmalarda bunun sebeplerinin ortaya konması yararlı olacaktr. 


\section{KAYNAKÇA}

Akçay, V. Hilal. (2012). Pozitif Psikolojik Sermayenin İş Tatmini Ille ilişkisi. Kahramanmaraş Sütçü Imam Üniversitesi Iktisadi ve Idari Bilimler Fakültesi Dergisi, Cilt: 2, Sayı: 1.

Aksu, Akın (1995). Otel işletmelerinde İşgören Devir Hızının Verimlilikle Olan İlişkisinin Değerlendirilmesi ve Antalya Yöresinde Bir Uygulama, Akdeniz Üniversitesi Sosyal Bilimler Enstitüsü, Yüksek Lisans Tezi, Antalya.

Anderson, Gary (1990). Fundementals of Educational Research, London et al: The Farmer Press.

Ashforth, Blake E. ve Humphrey, Ronald H. (1995), Emotion in the Workplace: A Reappraisal, Journal of Human Relations, Volume 48, Issue: 2, pp. 97-125.

Aşan, Öznur ve Özyer, Kubilay (2008). Duygusal Bağılııkları ile Iş Tatmini ve İş Tatmininin Alt Boyutları Arasındaki İlişkileri Analiz Etmeye Yönelik Ampirik Bir Çalışma. Süleyman Demirel Üniversitesi İktisadi ve İdari Bilimler Fakültesi Dergisi, Cilt:13, Sayı:3, 129-151.

Balcı, Ali (2005). Sosyal Bilimlerde Araştırma, Pegem Yayıncılık, Ankara.

Baş, Türker ve Ardıç, Kadir (2002). Yükseköğretimde iş tatmini ve tatminsizliği. i̇ktisat İşletme ve Finans, 17, Eylül, 72-81.

Baycan, F.A. (1985). "Farklı Gruplarda Çalışan Kişilerde iş Doyumunun Bazı Yönlerinin Analizi", Boğaziçi Üniversitesi, Bilim Uzmanlığı Tezi, İstanbul.

Biçkes, Mehmet Durdu ve Yılmaz, Celal; Demirtaş, Özgür; Uğur, Ayşegül (2014). “Duygusal Emek ile İş Tatmini Arasındaki İlişkide Psikolojik Sermayenin Aracılıkk Rolü: Bir Alan Çalışması”, Eskişehir Osmangazi Üniversitesi i.i.B.F Dergisi, Ağustos, 9(2), s.s.: 97-121.

Çalışkan, S. Cihan. ve Erim, A. (2010). Pozitif Örgütsel Davranış (POD) Değişkenleri Ile Yeni Araştırma Modelleri Kurma Arayışları: POD'un İşe Adanmışlık, Tükenmişlik Ve Sinizm Üzerindeki Etkileri. 18. Yönetim Organizasyon Kongresi Kitabı, 658-671.

Çetin, Fatih ve Basım, H. Nejat (2012). "Örgütsel Psikolojik Sermaye: Bir Ölçek Uyarlama Çalışması", Amme Idaresi Dergisi, Cilt 45, Sayı 1, ss. :121-137.

Churcill Jr., G.A; Ford, N.M., and Walker Jr., O.C. (1974). Measuring the Job Satisfaction of Industrial Salesmen, Journal of Marketing Research, 11, pp. 254-260.

Comer, J.M.; Machleit, K.A.; Lagace, R.R. (1989). Pschometric Assessmentof a Reduced Version of INDSALES", Journal of Business Research, Vol. 18, June, pp. 291-332.

Davis, Keith (1998). İşletmede İnsan Davranışı. Arizona State University, 5. Baskı, i̇.Ü. İşletme Fakültesi Yayını, No:199, 96.

Demirdağ, Şerif Ahmet (2015). Örgütsel Güven ve iş Tatmini Arasındaki ilişki: Otel İşletmeleri Üzerine Bir Araştırma Gazi Üniversitesi, Sosyal Bilimler Enstitüsü, Yüksek Lisans Tezi, Ankara.

Demirel, Reyhan (1989). "Yaş, Cinsiyet ve Mesleki Deneyimin Üniversite Kütüphanelerinde Çalışan Kütüphanecilerin İ̧̧ Tatminine Etkisi", Hacettepe Üniversitesi Sosyal Bilimler Enstitüsü, Yüksek Lisans Tezi, Ankara.

Erdil, Oya; Keskin, Erdal; İmamoğlu S. Zeki; Erat, Serhat (2004). Yönetim Tarzı ve Çalışma Koşulları, Arkadaşlık Ortamı ve Takdir Edilme Duygusu ile İş Tatmini Arasındaki İlişkiler: Tekstil Sektörlerinde Bir Uygulama. Doğuş Üniversitesi Dergisi, Cilt: 5, Sayı: 1, 17-26.

Eren, Erol (2004). Örgütsel Davranış ve Yönetim Psikolojisi. İstanbul: Doğuş Üniversitesi iïBF.

Ergin, C. (1992). Doktor ve Hemşirelerde Tükenmişlik ve Maslach Tükenmişlik Ölçeğinin Uyarlanması, VII. Ulusal Psikoloji Kongresi, Hacettepe Üniversitesi, Ankara.

Erkuş, Ahmet ve Afacan Fındıklı, Mine. (2013). “Psikolojik Sermayenin İş Tatmini, İş Performansı ve İşten Ayrıma Niyeti Üzerindeki Etkisine Yönelik Bir Araştrrma", İstanbul Üniversitesi İşletme Fakültesi Dergisi, Cilt: 42, Sayı: 2, ss.: 302- 318.

Gohel, Kirti (2012). Psychological Capital as a Determinant of Employee Satisfaction", International Referred Research Journal, 3, (36), pp. 34-37.

Gürbüz, S., Yüksel, M. (2008). Çalışma Ortamında Duygusal Zeka: İş Performansı, İş Tatmini, Örgütsel Vatandaşık Davranışı ve Bazı Demografik Özelliklerle Illişkisi. Doğuş Üniversitesi Dergisi, Cilt:9, Sayı:2, 174-190.

Kaplan, Metin ve Biçkes Mehmet Durdu. (2013). "The Relationship Between Psychological Capital and Job Satisfaction: A Study of Hotel Businesses In Nevşehir", Celal Bayar Üniversitesi I.i.i.B.F. Yönetim ve Ekonomi Dergisi, Cilt:20 Sayı:2, s.s.: 233-242. 
Keser, Sıtar ve Kocabaş, İbrahim (2014). Illköğretim Okulu Yöneticilerinin Otantik Liderlik ve Psikolojik Sermaye Özelliklerinin Karşılaştıııması. Kuram ve Uygulamada Eğitim Yönetimi, Cilt 20, Sayı 1, 1-2.

Luthans, Fred; Avolio, Bruce J.; Avey, James. B; Norman, Steven M. (2007a). “Positive Psychological Capital: Measurement and Relationship with Performance and Satisfaction", Published in Personnel Psychology, p.p. 541-572.

Luthans, Fred; Vogelgesang, Gretchen R; Lester, Paul (2007b). Developing the Psychological Capital of Resiliency. Human Resource Development Review, 5, 25-44.

Luthans, Fred; Youssef, Caroline M. (2004). Human, Social and now Positive Psychological Capital Management: Investing in People for Competitive Advantage. Organizational Dynamics, Vol. 33, 143-160.

Luthans, Fred (2002). The Need for and Meaning of Positive Organizational Behavior, Journal of Organization Behavior, Vol. 23, Issue 6, September, pp. 695-706.

MacInnis, D. J. ve Mello, G. E. (2005). The Concept Of Hope And Its Relevance To Product Evaluation And Choice, Journal of Marketing, 69, 1-14.

Oshagbemi, Titus (1999). Overall Job Satisfaction: How Good are Single Versus Multiple-Item Measures, Journal of Managerial Psychology, Vol. 14, Issue: 5, pp. 388-403.

Özer, P.S.; Topaloğlu, T.; Özmen, Ö.N.T. (2013), Destekleyici Örgüt İkliminin, Psikolojik Sermaye ile İş Doyumu Illişkisinde Düzenleyici Etkisi, Ege Akademik Bakış, Cilt: 13, Sayı 4, Ekim, ss. 437-447.

Stajkovic, Alexander D. ve Luthans, Fred (1998). Self- Efficacy and Work-Related Performance: A MetaAnalysis, Psyhological Bulletin, Vo.124, No:2, s.s. 240-261.

Şen, Cemal; Mert, İ. Sani; Aydın, Oğuz B., (2015) "Psikolojik Sermayenin Çalışanın Stresle Başa Çıkmasına, İş Tatminine ve Örgütsel Bağlılığa Etkisi”, 23.Ulusal Yönetim ve Organizasyon Kongresi, 14-16 Mayıs, Muğla.

Topçu, Mustafa Kemal ve Ocak, Metin (2012). Psikolojik Sermayenin Tükenmişlik Algısı Üzerine Etkisinde İş Tatmininin Aracılıkk Rolü: Türkiye ve Bosna-Hersek Sağlık Çalışanları Örneği , 20. Ulusal Yönetim ve Organizasyon Kongresi Bildiriler Kitabı, Dokuz Eylül Üniversitesi, 24-26 Mayıs, ss.: 685-690.

TÜik (2018a). İşgücü İstatistikleri, Ekim 2017, Haber Bülteni, Sayı: 27691, Yayınlanma Tarihi: 15 Ocak 2018, Saat: 10.

TÜík (2018b). Cinsiyete Göre İşücü, Tüik Veri Tabanı, <https://biruni.tuik.gov.tr/medas/?kn=102\&locale=tr>, Erişim Tarihi: 31 Ocak.

Uygungil, Selen (2017). Pozitif Psikolojik Sermaye ile Çalışan Tutumları Arasındaki ilişkilerin İncelenmesi: Adana İlinde Bir Uygulama, T.C. Atatürk Üniversitesi, Sosyal Bilimler Enstitüsü, İşletme Anabilim Dalı, Yayımlanmamış Yüksek Lisans Tezi, 1-275. 